\title{
Enhancement of Macrophage Candidacidal Activity by Interferon- $\gamma$ \\ Increased Phagocytosis, Killing, and Calcium Signal \\ Mediated by a Decreased Number of Mannose Receptors
}

\author{
Lászlo Maródi, * " Stefan Schreiber, " Donald C. Anderson," Richard P. MacDermott," \\ Helen M. Korchak, * and Richard B. Johnston, Jr.* " \\ Departments of ${ }^{*}$ Pediatrics and ${ }^{\S}$ Medicine, University of Pennsylvania School of Medicine, Philadelphia, Pennsylvania 19104; \\ "Department of Pediatrics, Baylor School of Medicine, Houston, Texas 77030; ${ }^{\circ}$ Department of Pediatrics, University School of Medicine, \\ H-4012 Debrecen, Hungary; and 'Department of Pediatrics, Yale University School of Medicine, New Haven, Connecticut 06510
}

\begin{abstract}
In contrast to its macrophage-activating capacity, IFN- $\gamma$ downregulates expression of the macrophage mannose receptor (MMR), which mediates uptake of Candida and other microorganisms. We found that IFN- $\gamma$ induced a concentration-dependent increase in the capacity of human monocyte-derived macrophages to ingest and kill both opsonized and unopsonized Candida albicans and to release superoxide anion upon stimulation with Candida. Mannan or mannosylated albumin inhibited this activated uptake of unopsonized Candida, but glucan did not. Addition of $\mathrm{mAb}$ to complement receptor $(\mathrm{CR}) 3$ did not inhibit ingestion; macrophages that lacked CR3 (leukocyte adhesion defect ) showed normal upregulation of ingestion by IFN- $\gamma$. The increased candidacidal activity of IFN- $\gamma$-activated macrophages was associated with reduced expression of MMR by a mean of $79 \%$ and decreased pinocytic uptake of ${ }^{125}$ I-mannosylated BSA by $73 \% ; K_{\text {uptake }}$ of pinocytosis was not changed. Exposure of resident macrophages to unopsonized Candida did not elicit a transient increase in intracellular free $\mathrm{Ca}^{2+}$ $\left(\left[\mathrm{Ca}^{2+}\right]_{i}\right)$; macrophages activated by IFN- $\gamma$ expressed a brisk increase in $\left[\mathrm{Ca}^{2+}\right]_{i}$ on exposure to Candida. These data suggest that macrophage activation by IFN- $\gamma$ can enhance resistance to C. albicans infection in spite of downregulation of the MMR, perhaps through enhanced coupling of the MMR to microbicidal functions. (J. Clin. Invest. 1993. 91:2596-2601.) Key words: mannose receptor $\bullet$ macrophages $\bullet$ Candida $\bullet$ interferon$\gamma \cdot$ calcium
\end{abstract}

\section{Introduction}

Candida albicans is an increasingly important opportunistic pathogen in immunocompromised patients, but mechanisms of host defense against Candida are not completely understood (1). Experimental evidence suggests that mononuclear phagocytes could play an important role in eradication of Candida and that full expression of candidacidal functions may require

Dr. Schreiber's present address is Department of Medicine, University of Hamburg, D-2000, Hamburg 20, Germany.

Address correspondence to Dr. Richard B. Johnston, Jr., Department of Pediatrics, Yale University School of Medicine, 333 Cedar St., New Haven, CT 06510.

Received for publication 11 November 1992 and in revised form 22 January 1993.

J. Clin. Invest.

(c) The American Society for Clinical Investigation, Inc.

$0021-9738 / 93 / 06 / 2596 / 06 \quad \$ 2.00$

Volume 91, June 1993, 2596-2601 stimulation by activating agents (2-6). IFN- $\gamma$ has been the best-studied of the macrophage-activating cytokines (7).

Macrophages express on their surface a $175-\mathrm{kD}$ cell lineage-specific glycoprotein receptor that binds and internalizes both soluble and particulate ligands with terminal mannose residues (8-13). We have found that human monocyte-derived macrophages (macrophages) phagocytose unopsonized Candida primarily through this macrophage mannose receptor $(\mathrm{MMR})^{1}(4)$. In addition to the Candida species, the human MMR has been implicated in the uptake of other microorganisms, including Pseudomonas (11), Pneumocystis carinii (12), Leishmania donovani (13), and the Mycobacterium avium complex $(14,15)$. Expression of the MMR is highly susceptible to downregulation by macrophage-activating agents (16-18), an unexpected effect in view of the enhanced microbicidal capacity of activated macrophages.

This study was undertaken to investigate the effect of activation by IFN- $\gamma$ on macrophage anticandidal functions. We report here that treatment of human macrophages with IFN- $\gamma$ enhanced the capacity of these cells to ingest and kill $C$. albicans, as well as to release superoxide anion $\left(\mathrm{O}_{2}^{-}\right)$and exhibit an increase in intracellular free $\mathrm{Ca}^{2+}\left(\left[\mathrm{Ca}^{2+}\right]_{i}\right)$ upon stimulation with Candida. Both the rate and extent of mannose-inhibitable uptake of unopsonized Candida were increased in spite of a marked downregulation of the binding and pinocytic uptake of ${ }^{125}$ I-labeled mannose-BSA.

\section{Methods}

Monoclonal antibodies. mAb OKM1 (IgG2b) is directed against the lectin-like binding site of the $\alpha$-chain of complement receptor (CR) 3 as described $(19,20)$. mAb M1/70 (IgG2b; Boehringer Mannheim Corp., Indianapolis, IN) blocks binding sites for both $\mathrm{iC} 3 \mathrm{~b}$ and sugars on the $\alpha$ subunit of CR3 (19). The assays used saturating concentrations of mAbs determined by flow cytometry.

Monocyte-derived macrophages. Mononuclear cells were separated from the blood of normal adults using lymphocyte separation medium (Organon Teknika, Rockville, MD) and cultured in suspension with autologous serum and antibiotics for $3-5 \mathrm{~d}$ as described (4). In some experiments preparations were further enriched for monocytes using density centrifugation with Nycodenz monocytes (Nycomed, Oslo, Norway) $(4,21)$. All materials used to separate, culture, or assay macrophages were free of detectable endotoxin using the Limulus amebocyte lysate kit (Associates of Cape Cod, Woods Hole, MA) (4).

Treatment of macrophages with IFN- $\gamma$. Human rIFN- $\gamma$ was generously provided by Dr. Susan Kramer (Genentech, South San Fran-

1. Abbreviations used in this paper: CR, complement receptor; KRPD, Krebs-Ringer phosphate buffer with dextrose; LAD, leukocyte adhesion defect; Man-BSA, mannosylated BSA; MMR, macrophage mannose receptor; $\mathrm{O}_{2}^{-}$, superoxide anion. 
cisco, CA). At the concentrations indicated, IFN- $\gamma$ was added to macrophages after $72 \mathrm{~h}$ of culture, and incubation was continued for an additional $48 \mathrm{~h}$. Equivalent amounts of DME (GIBCO BRL, Gaithersburg, MD) were added as control.

Phagocytosis and binding assays. Phagocytosis of $C$. albicans (ATCC 18804, maintained and prepared as described [4]) was determined by incubating an equal number of macrophages and Candida for $60 \mathrm{~min}$ at $37^{\circ} \mathrm{C}$ under continuous rotation $(4 \mathrm{rpm})(4)$. At various times, $50-\mu \mathrm{l}$ aliquots of the mixture were removed to make cytospin preparations. These were stained with Diff-Quick (Baxter Healthcare Corp., Deerfield, IL) and the percentage of ingested yeast was determined (4). Candida yeasts within detectable phagocytic vacuoles were considered intracellular (4). Phagocytosis was also studied using yeasts conjugated with FITC (Sigma Chemical Co., St. Louis, MO) $(4,22)$. Fluorescence of Candida not fully ingested was extinguished by addition of $0.5 \mathrm{mg} / \mathrm{ml}$ crystal violet $(3,22)$.

Binding of Candida to macrophages was defined as a close association between $\sim 25 \%$ or more of the circumference of the yeast particle and the macrophage plasma membrane. Each experiment counted binding to macrophages in 200 high-power fields.

Candidacidal assay. Candida were mixed with a mononuclear cell suspension at a 1:1 ratio of Candida to macrophages and incubated for $60 \mathrm{~min}$ at $37^{\circ} \mathrm{C}$ under rotation $(4 \mathrm{rpm})(23)$. At various time points, $0.1-\mathrm{ml}$ aliquots were removed and the cells were disrupted by freezing and thawing, vortexed vigorously for $10 \mathrm{~s}$, diluted, and plated for colony counting (23). The freeze-thaw did not affect viability of the Candida (23).

Measurement of release of $\mathrm{O}_{2}^{-}$. Release of $\mathrm{O}_{2}^{-}$by macrophages was measured as the SOD-inhibitable reduction of ferricytochrome $c(23)$. Equal numbers of macrophages and Candida were incubated under rotation $(4 \mathrm{rpm})$.

Iodination of mannosylated BSA. Mannosylated BSA (Man-BSA; E-Y Laboratories, Inc., San Mateo, CA) was radiolabeled with $\mathrm{Na}^{125} \mathrm{I}$ by the chloramine $T$ method (24). Free iodine was removed by separation with Sephadex G-25 chromatography. 0.4-ml samples were collected and active fractions were identified by gamma counting. Protein was quantitated as described by Miller (25), and specific activity was typically $5-8 \times 10^{6} \mathrm{cpm} / \mu \mathrm{g}$ of Man-BSA protein, with $>95 \%$ of total counts being TCA precipitable. The preparation was used within 2 wk of iodination.

Determination of binding and uptake of ${ }^{125}$ I-Man-BSA by normal and IFN- $\gamma$-treated macrophages. Teflon beakers containing macrophages cultured with or without IFN- $\gamma$ were cooled in an ice bath for 30 min. The cell suspensions were transferred to $50-\mathrm{ml}$ polypropylene centrifuge tubes on ice, washed twice, and suspended in HBSS containing $10 \%$ HSA ( $\mathrm{pH} 7.1$; Cutter, Emeryville, CA). After addition of ${ }^{125} \mathrm{I}$ Man-BSA (final concentration, $20 \mu \mathrm{g}$ protein $/ \mathrm{ml}$ ) the incubation mixture containing $5 \times 10^{5}$ macrophages $(0.4 \mathrm{ml})$ was layered onto $1 \mathrm{ml}$ of a gradient of four parts Corning 702 oil (Fisher Scientific Co., Pittsburgh, PA) and one part Apiezon oil (Apiezon, London, UK) and incubated for $10 \mathrm{~min}$ at $0^{\circ} \mathrm{C}$ for binding assays or $37^{\circ} \mathrm{C}$ for pinocytosis. After incubation the cells were immediately centrifuged $\left(4^{\circ} \mathrm{C}, 10 \mathrm{~min}\right.$, $16,000 \mathrm{~g}$ ) to separate cell-associated from unbound ligands. The oil was then frozen in dry ice-ethanol, and the cell-bound gamma radioactivity was measured in the cut pellet. Nonspecific binding or uptake, determined in the presence of $2 \mathrm{mg} / \mathrm{ml}$ mannan (Sigma Chemical Co.), was $<15 \%$ and was subtracted from the total counts per minute to determine specific binding or uptake (26). All determinations were carried out in duplicate. $K_{\text {uptake }}$ was calculated by graphical estimation from the double reciprocal plot (26).

Measurement of $\left[\mathrm{Ca}^{2+}\right]_{i}$. Suspensions of macrophages were treated with fura- $2 \operatorname{AM}(4,27,28)$, centrifuged at $200 \mathrm{~g}$ for $5 \mathrm{~min}$, and resuspended at a concentration of $10^{7}$ macrophages $/ \mathrm{ml}$ in KrebsRinger phosphate buffer with dextrose (KRPD). Immediately before use, a $0.5-\mathrm{ml}$ cell suspension was centrifuged and the cells were resuspended in $2 \mathrm{ml}$ of $37^{\circ} \mathrm{C}$ buffer and added to a heated $\left(37^{\circ} \mathrm{C}\right)$ cuvette in which they were stirred continuously. Candida $\left(10^{7}\right.$ in $50 \mu \mathrm{l}$ buffer $)$ were added to begin the reaction, and fluorescence changes were moni- tored. Changes in fluorescence intensity caused by Candida alone were subtracted from those obtained with phagocytes stimulated with $\mathrm{Can}$ dida (4).

Expression of data. Results are expressed as mean \pm SEM. $n$ refers to the number of experiments, each done in duplicate or triplicate. Statistical significance was determined by $t$ test or analysis of variance (ANOVA), as indicated.

\section{Results}

Effects of IFN- $\gamma$ on phagocytic uptake of Candida and release of $\mathrm{O}_{2}^{-}$. Preincubation of macrophages with IFN- $\gamma$ for $48 \mathrm{~h}$ induced a concentration-dependent increase in the uptake of unopsonized $C$. albicans and in C. albicans-stimulated release of $\mathrm{O}_{2}^{-}$(Fig. 1). Maximal activity for both functions occurred at a concentration of $100 \mathrm{U} / \mathrm{ml}$, with no appreciable increase being achieved by treatment of cells with $200 \mathrm{U} / \mathrm{ml}$ (Fig. 1) or 500 $\mathrm{U} / \mathrm{ml}(n=7$; not shown $)$.

The time course of phagocytic uptake and release of $\mathrm{O}_{2}^{-}$ after incubation of macrophages with $100 \mathrm{U} / \mathrm{ml}$ IFN- $\gamma$ or buffer alone is shown in Fig. 2. Treatment of macrophages with IFN- $\gamma$ resulted in a significantly higher degree of ingestion of unopsonized Candida compared with phagocytosis by untreated (resident) cells over a 60 -min incubation (Fig. 2, left; $P$ $<0.01$, ANOVA). The rate and extent of release of $\mathrm{O}_{2}^{-}$were markedly increased by preincubation of macrophages with IFN- $\gamma$ (Fig. 2, right; $P<0.001$, ANOVA).

In an attempt to explore the basis for the increased uptake by macrophages treated with IFN- $\gamma$, we studied binding at an early time point $(5 \mathrm{~min}$ ), before detectable ingestion had occurred. Binding of $C$. albicans to IFN- $\gamma$-treated and nontreated macrophages after 5 min of incubation was not significantly different ( $11 \pm 5$ and $9 \pm 6 \%$, respectively; $n=4)$. The percentage of macrophages ingesting at least one Candida yeast after $60 \mathrm{~min}$ of incubation was also equivalent for the IFN- $\gamma$-treated cells $(67 \pm 7 \%)$ and for untreated cells $(65 \pm 5 \%)(n=5)$. However, the number of Candida ingested per macrophage was higher for the IFN- $\gamma$-treated cells (Fig. 1 and Fig. 2, left).

We compared the phagocytosis of fully opsonized $C$. albicans ( $2.5 \%$ fresh human serum) (4) by resident and IFN- $\gamma$ treated macrophages. Phagocytosis was more rapid than that

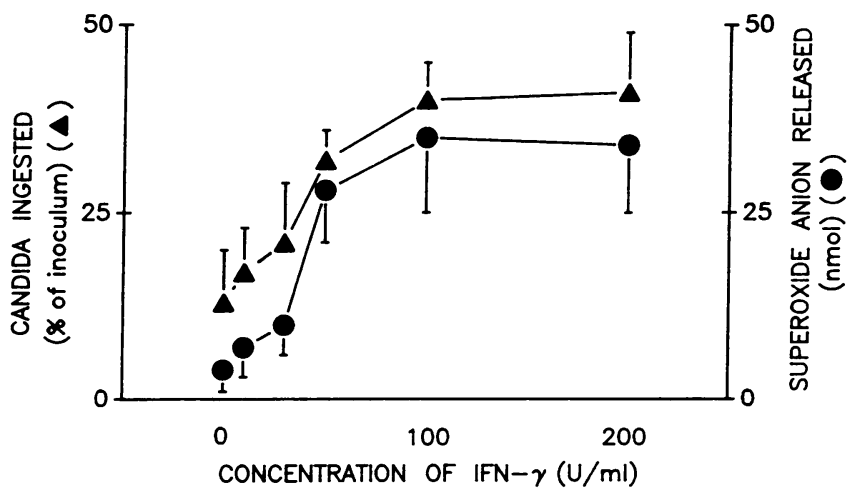

Figure 1. Concentration-dependent effect of IFN- $\gamma$ on phagocytosis of unopsonized Candida (triangles) and release of $\mathrm{O}_{2}^{-}$(circles) by human monocyte-derived macrophages. Incubation with IFN- $\gamma$ was for $48 \mathrm{~h}$. Phagocytic uptake and $\mathrm{O}_{2}^{-}$release were measured in suspensions of macrophages and $C$. albicans $\left(5 \times 10^{6} / \mathrm{ml}\right.$ for each $)$ after $30 \mathrm{~min}$ of incubation. Data represent mean $\pm \operatorname{SEM}(n=7)$. 


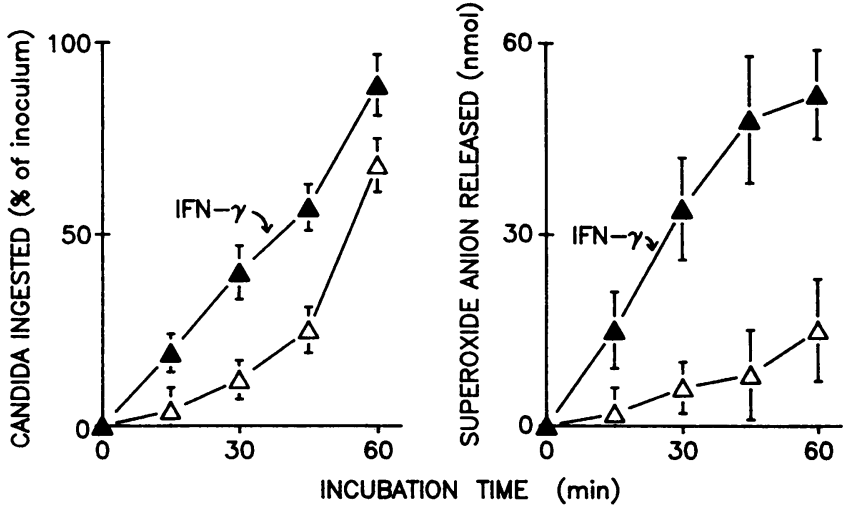

Figure 2. Time courses of phagocytosis of unopsonized candida (left) and release of $\mathrm{O}_{2}^{-}$(right). The extent of these activities is plotted as a function of time after addition of $C$. albicans to an equal number of macrophages $\left(5 \times 10^{6}\right)$ in suspension. Results are compared for macrophages treated with IFN- $\gamma$ (filled symbols) or untreated (open symbols $)$. Mean $\pm \operatorname{SEM}(n=6)$.

with unopsonized Candida, as shown previously (4): total phagocytic uptake of opsonized Candida by IFN- $\gamma$-treated macrophages after 10 min of incubation was $64 \pm 7 \%$ of inoculum, compared with $38 \pm 9 \%$ by resident macrophages; uptake was $89 \pm 9$ and $61 \pm 7 \%$, respectively, after $20 \mathrm{~min}$ of incubation ( $n=5-6, P<0.01$ at both time points).

Effect of IFN- $\gamma$ on macrophage candidacidal activity. The increased phagocytic activity and $\mathrm{O}_{2}^{-}$release of IFN- $\gamma$-treated macrophages were accompanied by an enhanced capacity of these cells to kill the ingested, unopsonized fungi (Fig. 3). Macrophages treated with $100 \mathrm{U} / \mathrm{ml}$ IFN- $\gamma$ killed three to five times more $C$. albicans than did untreated cells at the various time points studied (Fig. 3, $P<0.001$, ANOVA).

Evidence that the enhanced phagocytosis of Candida by IFN- $\gamma$-treated macrophages is mediated by binding through the $M M R$. Human macrophages phagocytose unopsonized Candida species primarily through the mannose receptor (4). We investigated the involvement of mannose receptors in the uptake of unopsonized $C$. albicans by macrophages activated with IFN- $\gamma$ by studying phagocytosis in the presence or absence of mannan, Man-BSA, or glucan. Both mannan and Man-BSA inhibited uptake of Candida in a concentration-dependent fashion; slight but insignificant inhibition of ingestion could be detected at a high concentration of glucan (Table I). These findings are equivalent to those with resident macrophages (4), suggesting that ingestion in IFN- $\gamma$-treated macrophages also depends primarily on binding and uptake through the mannose receptor.

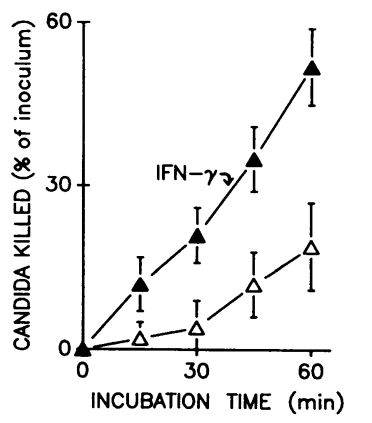

Figure 3. Time course of intracellular killing of unopsonized $C$. albicans by macrophages that were IFN- $\gamma$ treated $(100 \mathrm{U} / \mathrm{ml}$; filled symbols) or untreated (open symbols). Mean \pm SEM $(n=6-8)$.
We explored the possibility that macrophage CR3 might be involved in the ingestion of unopsonized Candida after treatment with IFN- $\gamma$, based on studies showing that this receptor can bind carbohydrate ligands $(19,20,29)$. There was no inhibition of phagocytosis when mAbs reactive with the carbohydrate-binding site of CR3 were present throughout the 30-min incubation of unopsonized Candida with macrophages $(44 \pm 6$ and $39 \pm 9 \%$ phagocytosis in the presence of $10 \mu \mathrm{g} / \mathrm{ml} \mathrm{OKM1}$ or M1 / 70, respectively, compared with $42 \pm 6 \%$ phagocytosis in the absence of antibody; mean $\pm \mathrm{SEM}, n=5$ ). Preincubation of macrophages for $25 \mathrm{~min}$ with $10 \mu \mathrm{g} / \mathrm{ml}$ of the mAbs still had no effect ( $n=5$; data not shown). In control experiments, OKM 1 and M1 / 70 mAbs effectively inhibited uptake and killing of unopsonized type III group B streptococci by IFN- $\gamma$ treated macrophages, a process reported to depend on the lectin-like binding site on CR3 (19) (killing in the absence of antibody, $15 \pm 10 \%$; in the presence of OKM1, $3 \pm 3 \%$; in the presence of $\mathrm{M} 1 / 70,5 \pm 4 \% ; n=5-7$ ). These mAbs did not opsonize the Candida by reacting with the candidal CR3 analogue: Candida that were preincubated with buffer or with $\mathrm{mAbs}$ at $37^{\circ} \mathrm{C}$ for $25 \mathrm{~min}$ and then washed were ingested to the same extent (data not shown).

Monocyte-derived macrophages from two patients with leukocyte adhesion defect (LAD), which do not express CR3 (20), ingested unopsonized Candida as effectively as did normal macrophages (70 and $74 \%$ ingestion by LAD macrophages, 66 and $80 \%$ ingestion by paired normal macrophages, 60-min incubation ). Macrophages from one patient with LAD showed normal enhancement in Candida uptake after treatment for $48 \mathrm{~h}$ with IFN- $\gamma$ : for both control and patient, IFN- $\gamma-$ treated cells (compared with resident cells) had about three times greater ingestion at $15-\mathrm{min}$ incubation and about two times greater ingestion at $30 \mathrm{~min}$; at $60 \mathrm{~min}$, ingestion was $86 \%$ of inoculum by the patient's cells and $90 \%$ by the control.

There is a structural analogue of CR3 on the outer surface of $C$. albicans $(19,29,30)$; CR3 has been reported to bind carbohydrate ligands in addition to $\operatorname{iC} 3 b(19,29,30)$. We explored the theoretical possibility that a mannose-binding struc-

Table I. Effects of Mannan, Man-BSA, and Glucan on the Phagocytosis of Unopsonized Candida by IFN- $\gamma$-treated Macrophages

\begin{tabular}{lccc}
\hline Mannan & Man-BSA & Glucan & $\begin{array}{c}\text { Phagocytosis } \\
\text { of } C \text {. albicans by } \\
\text { macrophages }\end{array}$ \\
\hline$m g / m l$ & $\mu g$ mannose/ml & $m g / m l$ & $\%$ of inoculum* \\
- & - & - & $95 \pm 4(7)$ \\
0.1 & - & - & $72 \pm 11(4)$ \\
1 & - & - & $55 \pm 8(5)$ \\
5 & - & - & $23 \pm 7(5)$ \\
- & 6.4 & - & $51 \pm 10(6)$ \\
- & 64 & - & $29 \pm 4(4)$ \\
- & 320 & - & $17 \pm 6(5)$ \\
- & - & 5 & $81 \pm 6(5)$ \\
\hline
\end{tabular}

Macrophages $\left(5 \times 10^{6} / \mathrm{ml}\right)$ were incubated with an equal number of Candida for $60 \mathrm{~min}$ at $37^{\circ} \mathrm{C}$ under rotation $(4 \mathrm{rpm})$. The polysaccharide compounds were added at the beginning of the incubation with the Candida (not preincubated). * Data represent mean \pm SEM $(n)$. 
ture in this CR3 analogue on C. albicans might facilitate phagocytosis through binding to some mannose-bearing structure on the surface of macrophages. We therefore preincubated C. albicans $\left(5 \times 10^{6} / \mathrm{ml}\right)$ with Man-BSA ( $64 \mu \mathrm{g}$ mannose $\left./ \mathrm{ml}\right)$ for 25 $\min$ at $37^{\circ} \mathrm{C}$, centrifuged and washed twice with buffer, and studied phagocytosis. There was no inhibition of uptake by this treatment $(49 \pm 12$ and $44 \pm 11 \%$ phagocytosis of Man-BSAtreated and untreated Candida, respectively; 30 -min incubation; mean \pm SEM, $n=5$ ).

Effect of IFN- $\gamma$ on the binding and uptake of ${ }^{125}$ I-Man-BSA by macrophages. Experiments were performed at $0^{\circ} \mathrm{C}$ to estimate the effect of incubation with IFN- $\gamma$ for $48 \mathrm{~h}$ on the number and affinity of MMR. The amount of ${ }^{125}$ I-Man-BSA ligand bound to macrophages decreased by $79 \pm 19 \%(n=5)$ in the IFN- $\gamma$-treated cells without changes of the affinity: $K_{\mathrm{d}}$ was 3-5 $\times 10^{-8} \mathrm{M}$ for both untreated cells and cells treated with 100

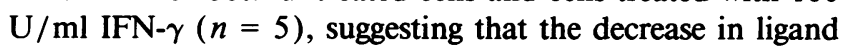
binding reflects a decrease in receptor density rather than binding affinity.

As shown in Table II, treatment with IFN- $\gamma$ resulted in a concentration-dependent decrease in the capacity of macrophages to pinocytose ${ }^{125} \mathrm{I}-\mathrm{Man}-\mathrm{BSA}$ at $37^{\circ} \mathrm{C}$. Inhibition at 100 $\mathrm{U} / \mathrm{ml}$ IFN- $\gamma$ was $83 \pm 2 \%$. Kinetics of the pinocytic uptake of ${ }^{125}$ I-Man-BSA were investigated in macrophages treated with $100 \mathrm{U} / \mathrm{ml} \mathrm{IFN-} \gamma$ (Fig. 4). $K_{\text {uptake }}$, the concentration of ligand at which uptake is half-maximal, was estimated graphically using double reciprocal plots. Treatment with IFN- $\gamma$ decreased the $V_{\max }$ of ${ }^{125} \mathrm{I}$-Man-BSA uptake by $73 \pm 6 \%(n=3)$ without altering the $K_{\text {uptake }}$ of pinocytosis (3-4 $\times 10^{-8} \mathrm{M}$ for both untreated and IFN- $\gamma$-treated cells). These findings suggest that the decreased pinocytic rate of ${ }^{125}$ I-Man-BSA by IFN- $\gamma$-treated macrophages also reflects a decrease in receptor number rather than affinity. Shepherd et al. have reported equivalent values for the $K_{\mathrm{d}}\left(\mathrm{O}^{\circ}\right)$ and $K_{\text {uptake }}\left(37^{\circ}\right)$ of the MMR of human monocyte-derived macrophages (31).

Candida-induced mobilization of $\left[\mathrm{Ca}^{2+}\right]_{i}$. Fig. 5 shows that addition of unopsonized Candida to resident macrophages elicits only a negligible change in $\left[\mathrm{Ca}^{2+}\right]_{\mathrm{i}}$. However, stimulation of IFN- $\gamma$-treated macrophages with unopsonized Candida triggers a rapid increase in $\left[\mathrm{Ca}^{2+}\right]_{\mathrm{i}}$ followed by a sustained level of increase in $\left[\mathrm{Ca}^{2+}\right]_{i}$ (Fig. 5). Peak $\left[\mathrm{Ca}^{2+}\right]_{i}$ was $69 \pm 8 \mathrm{nM}$ in resident macrophages and $110 \pm 9 \mathrm{nM}$ in activated macro-

Table II. Effect of IFN- $\gamma$ on the Pinocytic Uptake of Man-BSA by Macrophages

\begin{tabular}{cccc}
\hline & \multicolumn{3}{c}{ Uptake of ${ }^{125}$ I-Man-BSA by macrophages } \\
\cline { 2 - 4 } $\begin{array}{c}\text { Concentration } \\
\text { of IFN- } \gamma\end{array}$ & Donor 1 & Donor 2 & Donor 3 \\
\hline$U / m l$ & & $n g / 10$ min & \\
0 & 170 & 260 & 124 \\
10 & 119 & 183 & 105 \\
50 & 76 & 62 & - \\
100 & 24 & 43 & 26 \\
500 & 11 & 17 & 14 \\
\hline
\end{tabular}

Macrophages from three donors were incubated for $48 \mathrm{~h}$ with the concentrations of IFN- $\gamma$ shown. These cells were washed and incubated for $10 \mathrm{~min}$ at $37^{\circ} \mathrm{C}$ with $20 \mu \mathrm{g} / \mathrm{ml}{ }^{125} \mathrm{I}-$ Man-BSA. Specific uptake is shown (average of duplicates). Nonspecific uptake was always $<15 \%$ of total uptake as assessed in the presence of $2 \mathrm{mg} / \mathrm{ml}$ mannan.
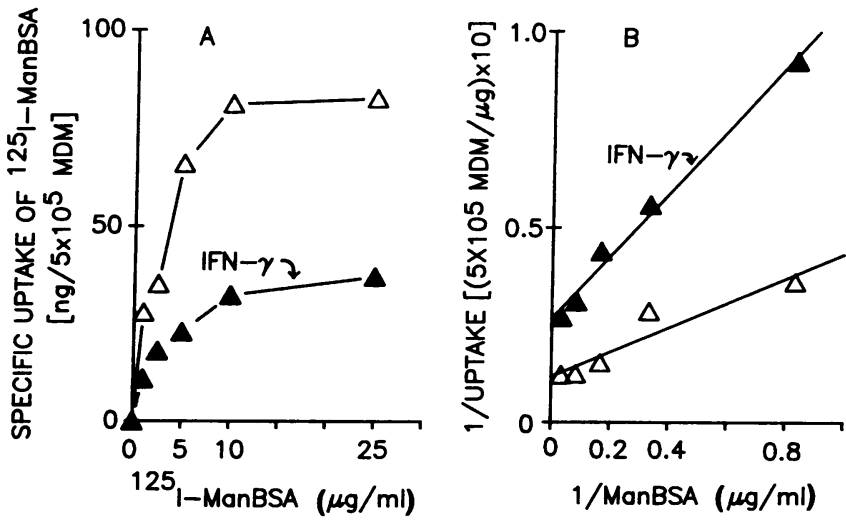

Figure 4. Specific uptake of ${ }^{125} \mathrm{I}-\mathrm{Man}-\mathrm{BSA}$ by monocyte-derived macrophages $(M D M)$ cultured for $48 \mathrm{~h}$ with or without IFN- $\gamma(100$ $\mathrm{U} / \mathrm{ml}$ ). Macrophages were incubated with ${ }^{125} \mathrm{I}-\mathrm{Man}-\mathrm{BSA}$ at $37^{\circ} \mathrm{C}$ for $10 \mathrm{~min}$ and then cells were separated from media by centrifugation through oil. Nonspecific binding, as assessed in the presence of 2 $\mathrm{mg} / \mathrm{ml}$ mannan, was $<15 \%$ and was subtracted. The results shown are averages of duplicate values in one representative experiment of three performed.

phages $(n=4 ; P<0.001)$. Resting concentrations of $\left[\mathrm{Ca}^{2+}\right]_{\mathrm{i}}$ in resident and IFN- $\gamma$-activated macrophages were comparable $(66 \pm 9$ and $64 \pm 5 \mathrm{nM}$, respectively; $n=4)$.

\section{Discussion}

A plasma membrane receptor for ligands with terminal mannose residues, the MMR, has been defined on human and rodent macrophages $(4,8-13,31)$. A similar receptor has been identified on human retinal pigmented epithelium (32). These mannose receptors can mediate endocytic clearance of glycoproteins, including enzymes from neutrophils, rod outer segments, and tissue-type plasminogen activator (32-34); and the MMR can mediate phagocytosis of microorganisms (4, 1115 ). Expression of surface MMR can be downregulated during macrophage activation (16-18) and upregulated by corticosteroids, prostaglandin E, and IL-4 (34-36). The capacity of the MMR to clear mannose-containing proteins has been used to target replacement of the deficient enzyme in Gaucher's disease (37).

In agreement with the observations of others with activated macrophages (16-18), we found that treatment with IFN- $\gamma$ decreased the number of MMRs and the extent of MMR-mediated pinocytosis of Man-BSA by macrophages. By treatment with IFN- $\gamma$, however, macrophages achieved an increased capacity to ingest and kill unopsonized Candida. This finding was contrary to our expectations since we had previously demonstrated that the uptake of unopsonized Candida by untreated macrophages selectively involved the MMR. Thus, downregulation by IFN- $\gamma$ of the number of MMRs on the surface of activated macrophages inhibited pinocytosis of mannose conjugates but did not decrease MMR-mediated phagocytosis.

IFN- $\gamma$ has been reported to increase both the number and function of receptors for IgG (FcR) on human mononuclear phagocytes $(38,39)$. In contrast, the number of macrophage receptors for C3b (CR1) and iC3b (CR3) appeared unaffected by IFN- $\gamma$ treatment, but binding and uptake through these 


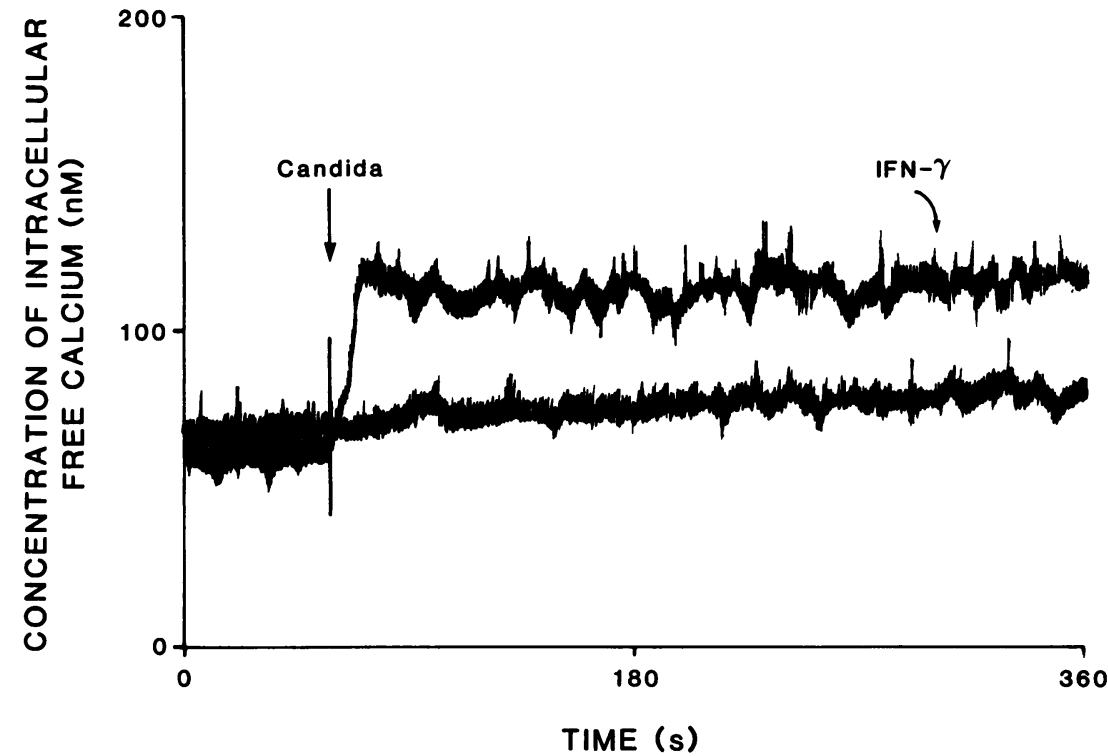

Figure 5. Effect of activation of macrophages by IFN- $\gamma$ on the increase in $\left[\mathrm{Ca}^{2+}\right]_{i}$ stimulated by exposure to unopsonized $C$. albicans. $\left[\mathrm{Ca}^{2+}\right]_{i}$ was quantitated using fura-2 fluorescence with macrophages suspended in a heated $\left(37^{\circ} \mathrm{C}\right)$ cuvette with stirring $(4,28)$. Results were compared with IFN$\gamma$-activated (labeled) and resident macrophages; addition of Candida is indicated by the arrow. The results shown are reproductions of actual tracings and representative of results found in four separate experiments. receptors were decreased (40). These results were confirmed for CR3 (41). Our findings, therefore, represent a second example of a dissociation between the effects of IFN- $\gamma$ on the number of receptors expressed on the membrane and the function of those receptors.

Our data strongly support the concept that the uptake and killing of unopsonized Candida by IFN- $\gamma$-activated macrophages are mediated primarily by the MMR. Phagocytosis was inhibited easily by mannan and small concentrations of BSAconjugated mannose added along with the Candida. CR3, the other macrophage receptor that has been recognized to mediate uptake of carbohydrate ligands, appeared to be involved minimally if at all: two mAbs that block the carbohydratebinding site on CR3 did not reduce ingestion of unopsonized Candida by IFN- $\gamma$-activated macrophages. Macrophages from patients with LAD, which lack CR3, ingested unopsonized Candida normally before and after activation by IFN- $\gamma$. In addition, it has been reported that IFN- $\gamma$ treatment decreases the phagocytosis-promoting activity of CR3 on human macrophages $(40,41)$, and we found that IFN- $\gamma$ enhanced ingestion in our system.

We are unaware of published data that relate MMR function in the macrophage to specific elements of the signal transduction pathway. We report here that IFN- $\gamma$-activated macrophages expressed a prominent rise in $\left[\mathrm{Ca}^{2+}\right]_{\mathrm{i}}$ on exposure to unopsonized Candida, whereas resident macrophages showed no $\mathrm{Ca}^{2+}$ transient when similarly exposed. These results suggest that macrophage activation may alter MMR-mediated signal transduction. It has been proposed that $\left[\mathrm{Ca}^{2+}\right]_{i}$ is a second messenger in the signal transduction relevant to the generation of oxygen metabolites by phagocytic cells (27), and it has been demonstrated that exposure of neutrophils to endotoxin primes them for a marked increase in the rise in $\left[\mathrm{Ca}^{2+}\right]_{i}$ and release of $\mathrm{O}_{2}^{-}$that result from exposure to chemotactic peptide (28). It seems likely that the $\mathrm{Ca}^{2+}$ response in IFN- $\gamma$-treated macrophages observed in this study plays a part in the increased $\mathrm{O}_{2}^{-}$production and killing of Candida exhibited by these cells.

Taken together, our results support a role for the MMR in the increased ingestion and killing of Candida by IFN- $\gamma$ - activated macrophages. This conclusion raises the possibility that IFN- $\gamma$ administration might have therapeutic use in candidal infection by enhancing the capacity of tissue macrophages to increase both opsonin-dependent and opsonin-independent uptake and killing of this increasingly serious pathogen.

\section{Acknowledgments}

We are grateful to Dr. Toshinori Moriguchi for analysis of LAD cells and to Dr. Susan Kramer, Genentech Corp., for the gift of human rIFN- $\gamma$.

This work was supported by U.S. Public Health Service grants AI24782, AI-24840, DK-21474, and DK-33487 from the National Institutes of Health, by grants to Dr. Schreiber from the Deutsche Forschungsgemeinschaft and the Deutsche Gesselschaft furr Verdauungs und Softwechsel Krankheiten, and by grants to Dr. Maródi from the Hungarian Academy of Sciences (OTK A 1446) and the Central Laboratory of the Swiss Red Cross. Dr. Maródi was a participant in the USA-Hungary Health Scientists Exchange Program jointly funded by the Fogarty International Center and the Hungarian Ministry of Health.

\section{References}

1. Pfaller, M. A. 1989. Infection control: opportunistic fungal infections: the increasing importance of Candida species. Infect. Control Hosp. Epidemiol. 10:270-273.

2. Lehrer, R. I. 1975. The fungicidal mechanism of human monocytes. I. Evidence of myeloperoxidase-linked and myeloperoxidase-independent candidicidal mechanism. J. Clin. Invest. 55:338-346.

3. Sasada, M., and R. B. Johnston, Jr. 1980. Macrophage microbicidal activity. Correlation between phagocytosis-associated oxidative metabolism and the killing of candida by macrophages. J. Exp. Med. 152:85-98.

4. Maródi, L., H. M. Korchak, and R. B. Johnston, Jr. 1991. Mechanisms of host defense against Candida species. I. Phagocytosis by monocytes and monocyte-derived macrophages. J. Immunol. 146:2783-2789.

5. Wang, M., H. Friedman, and J. Y. Djeu. 1988. Enhancement of human monocyte function against Candida albicans by the colony-stimulating factors (CSF): IL-3, granulocyte-macrophage-CSF, and macrophage-CSF. J. Immunol. 143:671-677.

6. Perfect, J. R., D. L. Granger, and D. T. Durack. 1987. Effects of antifungal agents and $\gamma$-interferon on macrophage cytotoxicity for fungi and tumor cells. $J$. Infect. Dis. 156:316-323.

7. Johnston, R. B., Jr. 1988. Current concepts: monocytes and macrophages. N. Engl. J. Med. 318:747-752. 
8. Stahl, P. D., J. S. Rodman, M. J. Miller, and P. H. Schlesinger. 1978. Evidence for receptor-mediated binding of glycoproteins, glycoconjugates, and lysosomal glycosidases by alveolar macrophages. Proc. Natl. Acad. Sci. USA. 78:1399-1403.

9. Ezekowitz, R. A. B., K. Sastry, P. Bailly, and A. Warner. 1990. Molecular characterization of the human macrophage mannose receptor: demonstration of multiple carbohydrate recognition-like domains and phagocytosis of yeasts in Cos-1 cells. J. Exp. Med. 172:1785-1794.

10. Taylor, M. E., K. Bezouska, and K. Drickamer. 1992. Contribution to ligand binding by multiple carbohydrate recognition domains in the macrophage mannose receptor. J. Biol. Chem. 267:1719-1726.

11. Speert, D. P., S. D. Wright, S. C. Silverstein, and B. Mah. 1988. Functional characterization of macrophage receptors for in vitro phagocytosis of unopsonized Pseudomonas aeruginosa. J. Clin. Invest. 82:872-879.

12. Ezekowitz, R. A. B., D. J. Williams, H. Koziel, M. Y. K. Armstrong, A. Warner, F. F. Richards, and R. M. Rose. 1991. Uptake of Pneumocystis carinii mediated by the macrophage mannose receptor. Nature (Lond.). 351:155-158.

13. Wilson, M. E., and R. D. Pearson. 1986. Evidence that Leishmania donovani utilizes a mannose receptor on human mononuclear phagocytes to establish intracellular parasitism. J. Immunol. 136:4681-4688.

14. Bermudez, L. E., L. S. Young, and H. Enkel. 1991. Interaction of $\mathrm{Myco}$ bacterium avium complex with human macrophages: roles of membrane receptors and serum proteins. Infect. Immun. 59:1697-1702.

15. Roecklein, J. A., R. P. Swartz, and H. Yeager, Jr. 1991. Nonopsonic uptake of Mycobacterium avium complex by human monocytes and alveolar macrophages. J. Lab. Clin. Med. 119:772-81.

16. Ezekowitz, R. A. B., and S. Gordon. 1982. Down-regulation of mannosyl receptor-mediated endocytosis and antigen F4/80 in Bacillus-Calmette-Guerinactivated mouse macrophages. J. Exp. Med. 155:1623-1637.

17. Shepherd, V. L., R. Abdolrasulnia, M. Garrett, and H. B. Cowan. 1990 Down-regulation of mannose receptor activity in macrophages after treatment with lipopolysaccharide and phorbol esters. J. Immunol. 145:1530-1536.

18. Imber, M. J., S. V. Pizzo, W. J. Johnson, and D. O. Adams. 1980. Selective diminution of the binding of mannose by murine macrophages in the late stages of activation. J. Biol. Chem. 257:5129-5135.

19. Smith, C. L., C. J. Baker, D. C. Anderson, and M. S. Edwards. 1990. Role of complement receptors in opsonophagocytosis of group B streptococci by adult and neonatal neutrophils. J. Infect. Dis. 162:489-498.

20. Anderson, D. C., F. C. Schmalstieg, M. J. Finegold, B. J. Hughes, R. Rothlein, L. J. Miller, S. Kohl, M. F. Tosi, R. L. Jacobs, T. C. Waldrop, A. S. Goldman, W. T. Shearer, and T. A. Springer. 1985. The severe and moderate phenotypes of heritable Mac-1, LFA-1 deficiency: their quantitative definition and relation to leukocyte dysfunction and clinical features. J. Infect. Dis. 152:668-689.

21. Pawlowski, N. A., G. Kaplan, E. Abraham, and Z. A. Cohn. 1988. The selective binding and transmigration of monocytes through the junctional complexes of human endothelium. J. Exp. Med. 168:1865-1882.

22. Hed, J. 1977. The extinction of fluorescence by crystal violet and its use to differentiate between attached and ingested microorganisms in phagocytosis FEMS (Fed. Eur. Microbiol. Soc.) Microbiol. Lett. 1:357-361.

23. Marodi, L., J. R. Forehand, and R. B. Johnston, Jr. 1990. Mechanisms of host defense against Candida species. II. Biochemical basis for the killing of Candida by mononuclear phagocytes. J. Immunol. 146:2790-2794.

24. Konish, M., V. Shepherd, G. Holt, and P. Stahl. 1983. Uptake of glycoproteins and glycoconjugates by macrophages. Methods Enzymol. 98:301-304.
25. Miller, G. L. 1959. Protein determination for large numbers of samples Anal Chem. 31:964.

26. Shepherd, V. L., and P. D. Stahl. 1984. Macrophage receptors for lysosomal enzymes. In Lysosomes in Biology and Pathology. J. T. Dingle, R. T. Dean, and W. Sly, editors. Elsevier Science Publishers B. V., Amsterdam. 83-89.

27. Korchak, H. M., L. B. Vosshall, G_Zagon, P. Ljubich, A. M. Rich, and G Weissmann. 1988. Activation of the neutrophil by calcium-mobilizing ligands. I. A chemotactic peptide and the lectin concanavalin A stimulate superoxide anion generation but elicit different calcium movements and phosphoinositide remodeling. J. Biol. Chem. 263:11090-11105.

28. Forehand, J. R., M. J. Pabst, W. A. Phillips, and R. B. Johnston, Jr. 1989 Lipopolysaccharide priming of human neutrophils for an enhanced respiratory burst: role of intracellular free calcium. J. Clin. Invest. 83:74-83.

29. Gustafson, K. S., G. M. Vercellotti, C. M. Bendel, and M. K. Hostetter. 1991. Molecular mimicry in Candida albicans. Role of an integrin analogue in adhesion of the yeast to human endothelium. J. Clin. Invest. 87:1896-1902.

30. Heidenreich, F., and M. P. Dierich. 1985. Candida albicans and Candida stellatoidea, in contrast to other candida species, bind $\mathrm{iC} 3 \mathrm{~b}$ and $\mathrm{C} 3 \mathrm{~d}$ but not $\mathrm{C} 3 \mathrm{~b}$. Infect. Immun. 50:598-600.

31. Shepherd, V. L., E. J. Campbell, R. M. Senior, and P. D. Stahl. 1982. Characterization of the mannose / fucose receptor on human mononuclear phagocytes. J. Reticuloendothel. Soc. 32:423-431.

32. Shepherd, V. L., B. I. Tarnowski, and B. J. McLaughlin. 1991. Isolation and characterization of a mannose receptor from human pigment epithelium. Invest. Ophthalmol. \& Visual Sci. 32:1779-1784.

33. Otter, M., M. M. Barrett-Bergshoeff, and D. C. Rijken. 1991. Binding of tissue-type plasminogen activator by the mannose receptor. J. Biol. Chem. 266:13931-13935

34. Stahl, P. D. 1990. The macrophage mannose receptor: current status. Am J. Respir. Cell. Mol. Biol. 2:317-318.

35. Schreiber, S., J. S. Blum, J. C. Chappel, W. F. Stenson, P. D. Stahl, S. L. Teitelbaum, and S. L. Perkins. 1990. Prostaglandin E specifically upregulates the expression of the mannose receptor on mouse bone marrow-derived macrophages. Cell Regulat. 1:403-413.

36. Stein, M., S. Keshav, N. Harris, and S. Gordon. 1992. Interleukin 4 potently enhances murine macrophage mannose receptor activity: a marker of alternative immunologic macrophage activation. J. Exp. Med. 176:287-292.

37. Barton, N. W., R. O. Brady, J. M. Dambrosia, A. M. Di Bisceglie, S. H. Doppelt, S. C. Hill, H. J. Mankin, G. J. Murray, R. I. Parker, C. E. Argoff, et al. 1991. Replacement therapy for inherited enzyme deficiency: macrophage-targeted glucocerebrosidase for Gaucher's disease. N. Engl. J. Med. 324:1464-1470.

38. Guyre, P. M., P. M. Morganelli, and R. Miller. 1983. Recombinant immune interferon increases immunoglobulin G Fc receptors on cultured human mononuclear phagocytes. J. Clin. Invest. 72:393-397.

39. Jungi, T. W., P. G. Lerch, and M. Brcic. 1987. The effect of recombinant interferon- $\gamma$ on human monocyte-derived macrophages. Eur. J. Immunol. 17:735-738.

40. Wright, S. D., P. A. Detmers, M. T. Jong, and B. C. Meyer. 1986. Interferon- $\gamma$ depresses binding of ligand by $\mathrm{C} 3 \mathrm{~b}$ and $\mathrm{C} 3$ bi receptors on cultured hu man monocytes, an effect reversed by fibronectin. J. Exp. Med. 163:1245-1259.

41. Schlesinger, L. S., and M. A. Horwitz. 1991. Phagocytosis of Mycobacterium leprae by human monocyte-derived macrophages is mediated by complement receptors CR1 (CD35), CR3 (CD11b/CD18), and CR4 (CD11c/CD18) and IFN- $\gamma$ activation inhibits complement receptor function and phagocytosis of this bacterium. J. Immunol. 147:1983-1994. 